provided temptation for use in promotional the parallel increase in SOM scores with activities.

It is premature to assume that all betablocking drugs are equally effective in preventing sudden death and at present it is not known which subgroups of patients might benefit or for how long, and what doses are optimal. Every effort should be made to minimise speculation and over-simplification because of the danger of causing delays in the discovery of relevant mechanisms-or even worse of increasing scepticism and so depriving patients of effective treatment.

C W I OWENS

Department of Clinical Pharmacology,

University College Hospital

London WC1E 6JJ

${ }^{1}$ Peto R, Pike MC, et al. Br $\mathcal{F}$ Cancer 1977;35:1-39.

***The complete list of references for the diagram in the letter by $\mathrm{Dr}$ Baber and $\mathrm{Mr}$

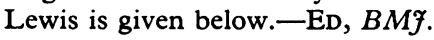

a Sowton E. (Quoting Fucella LM). Progr Cardiovas Dis 1968;10:561-74.

Norris RM, Caughey DE, Scott PJ. Br Med $\mathcal{F} 1968$;ii : 398-400.

Multicentre Trial. Lancet 1966;ii:1435.

Briant RB, Norris RM. NZ Med $\mathfrak{f}_{1970}$; $71: 135-8$ Baber NS, Evans DW, Howitt G, Thomas M, Wilson C. Br Heart $\mathcal{F} 1980 ; 44: 96-100$.

Whitlort $\mathcal{f} 1972 ; 34$ : 252-9. Balcon R, Jewitt Nielsen, Felsby M, Sch pnau Jorgensen F, Lyage Nielsen B, Roin J, Strange B. Lancet 1966; ;i: $920-4$ Walsh MJ. Acta Med Scand 1975;suppl 587:213-9. Barber JM, Murphy FM, Merrett JD. Ulster Med $1967 ; 36: 127-30$.

Mitchell JRA. Br Heart $\mathcal{f} 1978 ; 40$, suppl:88-93. Sloman G, Stannard M. Br Med J 1967;iv:508-12.

m Mitchell JRA. Br Heart f 1978;40, suppl:88-93. 1563 .

1563.
Multicentre International Study. $\mathrm{Br}$ Med $\mathcal{F} 1975$;ii 235-40.

p Wilhelmsson C, Vedin JA, Wilhelmsen L, Tibblin G, Werkö L. Lancet 1974; ;i: 1157-60.

q Snow PJD. Lancet 1965;ii:551-3.

Kahler RL, Brill SJ, Perkins WE. In: Katus AA, Ros G, Hall YE, eds. Cardiovascular Beta-adrenergic Responses. Los A
Press, 1968:213.

\section{Psychoneurotic profiles of}

\section{smokers and non-smokers}

SIR,-A 1975 health survey in Milton, a small rural township in New Zealand, ${ }^{1}$ gave very similar results ${ }^{2}$ to those reported by Dr Andrew $P$ Haines and his colleagues (14 June, p 1422) for the Northwick Park Heart Study (NPHS) participants.

The Middlesex Hospital Questionnaire subscale scores in the 992 New Zealand subjects (444 men and 548 women) grouped into smoking categories as in the study by $\mathrm{Dr}$ Haines and his colleagues were numerically similar to those of the NPHS. Subscale scores in a repeat survey in 1978 also were similar.

In our study ${ }^{2}$ also, with a few exceptions, women scored higher on the subscales than did the men and heavy smokers scored higher than "never smokers," and there was a tendency for scores to rise with increasing cigarette consumption. This was especially so for SOM (somatic concomitants of anxiety), which we found to be the subscale which showed the stepwise score increase with increasing cigarette consumption most clearly and to the highest statistical significance $(p<0.001$ analysis of variance).

Two of the questions asked in assessing SOM-namely, those concerning the occurrence of breathlessness and palpitationscould be associated with tobacco consumption in their own right. We found, however, that increasing consumption remained in both sexes even when these two questions were excluded and when only scores of the "respiratorily fit"'2 subjects were examined.

The tendency for scores to rise with increasing cigarette consumption points to a relationship between neuroticism and smoking, though which is cause and which is effect cannot be determined from these surveys alone.

\section{H J WAAL-MANNING} F A DE HAMEL

Wellcome Medical Research Institute and Department of Preventive and Social Medicine, University of Otago Medical School, Dunedin, New Zealand

1 Simpson FO, Nye ER, Bolli P, et al. NZ Med $\mathcal{F}$ 1978;87:379-82.

Waal-Manning HJ, de Hamel FA. NZ Med $\mathcal{F} 1978$;88:
188-91.

\section{Dietary prevention of ischaemic heart} disease coronary heart disease has failed and recommendations that these measures should be abandoned have already been published. ${ }^{1}$ Professor Barry Lewis's efforts (19 July, p 177) to restore faith in such measures are eithe unconvincing or incorrect.

Earlier emphasis on "dangerous" cholesterol has now given way to HDL:LDL ratios. Comparative death rates over decades are very insecurely based as doctors progressively change their diagnostic habits. Neithe Mackenzie nor Lewis was able to diagnose characteristic attacks of myocardial infarction in himself, lacking modern diagnostic confirmation. Improvement in the US mortality is part of a general increase in survival and coronary death rates have now fallen to the same level in the United States as in England and Wales, ${ }^{3}$ so we do not yet deserve a rebuke for our apparent inactivity.

The National Academy of Sciences and the National Research Council of America (surely the supreme court of science) have now reported ${ }^{4}$ that no prevention of coronary heart disease can be achieved by dietetic or drug reduction of blood cholesterol, except possibly when this is abnormal and there is a family history of such abnormality. The only response to this challenge by the polyunsaturated fat evangelists is not scientific but offensive innuendoes of malice and commercial influence, now rebutted by the

It is interesting to note the definition by Vergroesen $^{5}$ (who was vice-chairman of the FAO-UN report committee): "Atherosclerosis .... is characterised by deposits of esterified cholesterol . . . mostly from the blood lipoproteins... whose concentrations determine... the amount of accumulation subendothelially." Dr Vergroesen is director of research at Unilever and this definition provides the rationale of current commercial propaganda. The reasoning which makes this concept untenable can be summarised as follows:

(1) None of the best-conducted and statistically controlled trials of lipid-reducing polyunsaturatedfat diets or drugs have shown any preventive effects on the incidence or progress of coronary heart disease. Indeed, in the North Karelia (primary) and Sydney (secondary) ${ }^{7}$ prevention ${ }^{3}$ trials the controls fared better than groups treated with polyunsaturated fats.
SIR,-Evidence that dietary prevention of National Academy of Sciences.
(2) Only about $50 \%$ of atherosclerotic plaques contain any visible cholesterol, which is thus clearly not the cause. None of the spontaneously occurring hypercholesterolaemias (myxoedema, nephrosis, or even the rare homozygous form) are associated with any increased severity of ordinary coronary artery disease even after long exposure. The homozygous form can obstruct the coronary ostia only, leaving the coronary arteries virtually free of the disease.

(3) The butter- or cholesterol-fed rabbit lesion is part of a lipidosis in the arteries and other organs. The arterial lesions are really xanthomas and neither scar not thrombose, being wholly different in appearance and distribution from the human disease. It is only these dietary-induced lesions that regress with diet.

(4) Reproducing the familiar "jet lesion" and the localising effects of turbulence, experimental mechanical injury to the arterial lining produces at first a "pearly" fibrous plaque, which later contains cholesterol deposits at the naturally low levels of blood cholesterol of rabbits and sheep. ${ }^{8} 9$ Lipid accumulation is thus a secondary consequence, generated internally in the lesion, and it does not depend on flux of cholesterol from the plasma. It can ulcerate and thrombose and is the closest experimental model to the human disease. Coronary occlusive events in the individual patient are unrelated to blood cholesterol levels.

Thus atheroma almost certainly originates from platelet thrombosis and a cellular fibrous reaction on a site of endothelial injury and is quite unrelated to the cholesterol content of the blood.

It is deeply disturbing that some of our profession are stretching so much speculative and insecure evidence to support a dietetic theory no longer tenable by informed medical scientists. They wish to switch from our best dairy-based foods. They will try to change our agriculture. ${ }^{10}$ They have already persuaded the $\mathrm{BBC}$ to put out propaganda that these dietetic changes reduce coronary heart disease death rates in its recent home economics and nutritional programmes to schools. For this tatement there is no evidence.

The threat is serious. As a profession we cannot any longer permit or connive at this deception of the public.

JOHN MCMICHAEL

London NW11 7AA

1 McMichael J. Br Med f 1979;i:173.

2 Ahrens EH. Lancet 1979 ;ii: 1345.

3 Tunstall-Pedoe, H. Lancet 1980; : 831

National Academy of Sciences. Towards healthful diets. Washington: National Academy of Sciences, 1980

Vergroesen AJ, Gottenbos JJ, Ten Hoor F. Comprehensive Therapy 1979;5 (12):19.

Salonen JT, Puska P Mustaniemi H. Br Med $\mathcal{J}$

1979 ;ii:1178-82.

oodhill JM, Palmer AJ, Leelarthaepin B, McPaoletti R, Holmes W, eds. Drugs, lipid metabolism and atherosclerosis. New York: Plenum Press, 1979. 8 Moore S. Lab Invest 1973;29:478-87.

- Stehbens WE. Proc $R$ Soc London B 1974; 185 :357-73.

Centre for Agricultural Strategy, University of Reading. National food policy in the UK. University of Reading, 1979.

SIR,-In his excellent review "Dietary prevention of ischaemic heart disease-a policy for the ' 80 s" (19 July, p 177), Professor Barry Lewis refers to the strong positive correlations that have been established between plasma cholesterol concentrations and both mortality from ischaemic heart disease and the extent of coronary atherosclerosis. I deem it advisable to add a cautionary note, because the constituents measured as "cholesterol" could include other sterols.

Neither the older nor the newer clinical analytical methods in common $\mu$ se are specific for cholesterol: the enzyme cholesterol 